\title{
INCOGNITO
}

\section{AND THE NEW DIPLOMACY: THE CASE OF TSAR PETER}

\author{
«Who, but himself, ever left a Throne to learn to sit in it with more Grace?» ${ }^{1}$ \\ The Spectator, August 1711
}

Maija Jansson

Yale University

The aim of this article is to put Tsar Peter's traveling incognito in Holland and England into a wider context, to demonstrate that it was not an idiosyncratic choice on the Tsar's part but a mode of behavior taken from a new diplomatic protocol. One of the most vivid examples of the new mid-1 $17^{\text {th }}$ century conception of the term incognito is to be found in Peter's English experience. Using that experience as a focal point this article explains the evolution of the term itself in both literary usage and more broadly in diplomatic practice as it evolved at various congresses and assemblies of the period, beginning with the meetings preliminary to the signing of the Treaty of Westphalia. The article is based on various contemporary records and accounts, government documents and archives, as well as contemporary memoires. It concludes by showing that the practice of an ambassador or a monarch traveling incognito saved a governments' treasury the cost of elaborate ceremonials and a large entourage but more importantly for a monarch, it provided freedom of movement and escape from the constriction of the formalities of court rituals. Thus the actions of Peter I and also William III marked an important point in the transition from the formal ceremonial relations of personal monarchy at the beginning of the century to the later idea of the representation of the sovereign state by a regular corps of ambassadors and plenipotentiary ministers.

Key words: Incognito, Peter I, William III, diplomacy, Peace of Westphalia, personal monarchy, plenipotentiary ministers

УДК 93/94

Поступила в редакцию 01.10.2018 г.

Принята к публикации 10.12.2018 г.

\footnotetext{
1 The Spectator, 09.08.1711. Cited in Britain and Russia, in the age of Peter the Great, Historical Documents. Ed. by S. Dixon et al. London, School of Slavonic and East European Studies. Occasional Papers. 1998. No. 38 (122). P. 111.
} 
$\mathrm{F}$ rom the story of Richard Chancellor's first voyage in the middle of the sixteenth century through the accounts of ambassadors and merchants of the seventeenth, Englishmen grew more and more fascinated with Russia. Their perceptions of the people and society varied but the court itself was always perceived as rich and magnificent, brocaded and gilded, and the gifts brought by Russian ambassadors reflected that wealth. When, however, in 1698, the Tsar himself arrived in England dressed not in silk and sables but in the garb of a common foot soldier and occasionally a Dutch sailor, questions arose and misperceptions sometimes ensued. This article is an attempt to explain through English sources what incognito actually meant at the time and what it was that Peter sought to achieve through the device of traveling incognito. It is not intended to be a study in the language of diplomacy, but rather to suggest a different framework through which to assess Peter's first travels outside of Russia.

Peter I, Peter the Great, was the first Tsar to visit England and one of the first European rulers to travel abroad incognito ${ }^{2}$. The official announcement of his Grand Embassy was made in December 1696 and the journey itself began in the spring the following year [4, p. 7]. By June it had been reported in England that the Czar had arrived in Germany incognito and by August Sir William Trumbull had reported that «we are informed the Czar of Moscovia is coming to the Hague incognito from Hamburg by Bremen and Amsterdam ${ }^{3}$. For that great undertaking, Tsar Peter, twenty-six years of age and never having been out of his native land, went as part of the ambassadorial entourage of almost three hundred people under the guise of Petr Mikhailov, a decurion or militia man of one of three detachments of «volunteers» [6, p. 7]. While as traveler and visitor Peter chose to be incognito, as Tsar he had ambitious plans for meeting his ruling counterparts, discussing trade and alliances, and, perhaps most important to him, seeing the dockyards and learning the technologies and navigational techniques of the great western sea powers ${ }^{4}$.

After several months in Holland, all of the time incognito, through an arrangement with William III, English king and Dutch Stadtholder, a plan evolved for Peter to visit England..$^{5}$ Leaving Amsterdam on 7 January 1698 he arrived in London on the $11^{\text {th }}$ with his treasurer Aleksandr Menshikov, and accompanied by somewhere between nine and twenty-seven persons, the others remaining in Holland [6, p. 15; 16, p. 26;17, p. 239-244] ${ }^{6}$. Incognito crossing the North Sea, at the mouth of the Thames he disembarked in the

\footnotetext{
2 William III returned to Holland from England in 1691 incognito; See below. Earlier both Charles II and Queen Christina of Sweden had traveled incognito but not while enthroned.

$3 \mathrm{H}$ [istorical] M[anuscripts] C[ommission], Report on the Manuscripts of the Marquess of Downshire. In 2 Vols. London, 1924. Vol. II. Pp. 746, 755. Letter from Wolfgang von Schmettau, Ambassador of Brandenburg to the States General of the Netherlands, to Sir William Trumbull, June and August 1697, respectively.

4 See The Present State and Regulations of the Church of Russia. Vol. II. A Collection of Several Tracts. No. 1. «An account of the Rise of the Naval Power in Russia,» reprinted in Cracraft J. For God and Peter the Great, The Works of Thomas Consett 17231729. East European Monographs. No. XCVI. New York, 1982. Pp. 202-219.

5 B[ritish] L[ibrary] Add. 28900, ff. 364-365. Ellis papers. The accounts of Peter's travels are voluminous. See, for example, the English C[landar of] S[tate] P[apers] D[omestic]. William III. Pp. 1697, 1698. London 1927. Kraus reprint Nendeln, 1969 Index. Pierre Le Grand dans La Littérature Étrangére, compiled by R. Minzloff. St. Petersburg, 1872. All dates are given Old Style with the date change at the first of the year.

${ }^{6}$ He later sent back to Holland for his Chancellor F.A. Golovin and a second ambassador to assist in diplomatic matters. See The Austrian ambassadors' accounts. I thank Professor Paul Bushkovitch for the translation of the Austrian account.
} 
guise of a Dutch soldier but on coming up river to the City donned the more businesslike clothes of a Londoner, «with a wig» ${ }^{7}$.

As a result of the costuming and with it his general disregard for the ceremonies of court, Peter seemed a mystery. Because of his odd dress and idiosyncratic behavior and, perhaps, because that in itself encouraged a flare for the dramatic, he has been labeled by contemporary and modern writers alike as «unconventional,» «exotic,» «capricious,» «queer,» «a lousy barbarian,» and even «paranoid,» noting «his natural Romanov dread of a mob. $[13$, p. $316 ; 14$, p. $424 ; 20$, p. 428$] »^{8}$. And those epithets were often added to the earlier and well known discourses on «Russian Barbarism $»^{9}$. However, while all of those descriptions might hold a grain of truth, the quixotic nature of Peter's behavior stemmed primarily from the freedom allowed him by a new protocol, and it is this that calls for examination ${ }^{10}$. Peter appears to have been, in fact, more current with contemporary European diplomatic practices than were many English courtiers, with the exception of their King and several of the Secretaries of State. For most Englishmen the expectation was that Peter would arrive as a Tsar and be royally and ceremonially welcomed as such. As we know, however, that was not the case. In having chosen to be incognito Peter was advertising his desire to step outside of that focus by following a prototype from the diplomatic world. With that in mind we must look more closely at what incognito actually meant as the term changed in late seventeenth-century.

To the contemporary English and, indeed, to the Russians did incognito simply mean disguise? And was it Peter's own conceit? Could it be that Peter, a foot and one half taller than the average Englishman, and very thin, could really have been taken for anyone else? Of course not. As his own ambassador Franz Lefort wrote from Holland, «We are no longer hiding the fact of the tsar's presence as it would be pointless [11, p. 24]». Anthony Cross, a modern historian of Russia writes, «all was secret but all was known» [6, p. 17]. Nevertheless to the English lay person his conduct was odd because it was different.

What has been missed in the modern accounts of Peter's story is that by mid-century the term «incognito» had evolved into meaning something distinctively different from the word disguise, although elements of «disguise», «counterfeiting», and «impersonation» were inherent in the expanded idea, and hence Peter's costuming. Ultimately it was the incorporation of the concept of "privacy» into the term that led to its adaptation into the language of intra-European diplomatic practices of the period. Peter's activities in Holland and England were circumscribed by his being incognito in a very specific sense of the word. Quite simply, he borrowed for himself as Tsar a page from the new ambassadorial protocols that emerged in the diplomatic assemblies of the latter

\footnotetext{
7 HMC, Downshire, p. 746.

8 Simon Dixon et al. Britain and Russia, p. 1; B[einecke] R[are] B[ook] and M[anuscript] L[ibrary], Yale University, Blathwayt Papers, Box 2/12, letter 12.09.1697.

9 For bibliography and discussion of «Russian Barbarism,» see Hennings J. Russia and Courtly Europe. Pp. 35-44.

${ }^{10}$ I am using the late $19^{\text {th }}$ and early $20^{\text {th }}$ definition of protocol throughout which the Oxford English Dictionary (1973) gives as: Official, especially diplomatic procedure and etiquette in affairs of state and diplomatic relations; the observance of this. The accepted or established code of procedures, rules, and formalities.
} 
half of the $17^{\text {th }}$ century. He may have learned about the practice from diplomats visiting Russia, or the inspiration may have come from William III who himself had traveled incognito to the Hague six years earlier on his return in January 1692 from the accession to the English Crown, and «tho' he came as incognito yet he is received with the Noise of all the Cannon, ringing of bells, etc». Later, in March the same year, he returned to the city and it was reported then that «the King arrives incognito in an ordinary coach, but is soon known, and received with loud huzzas, etc». ${ }^{11}$ As with Peter later, «all was secret but all was known».

The evolution of the practice of being «incognito» also played a part in the transition from the institutions of court and household of earlier personal monarchies to the administrative units of modern states and the emergence of a professional diplomatic corps. By mid $17^{\text {th }}$ century traveling «incognito» was, to a certain extent, a practice born of necessity. It marked the beginning of the move away from the extravagant and conspicuous expenditures of large retinues and lavish ceremonials that had been an intrinsic part of sixteenth and earlier seventeenth-century diplomacy, Without these formalities the way was eased for diplomats at the larger late $17^{\text {th }}$ century congresses where they were empowered by rulers to meet and draft treaties but at which no rulers were present. In short, being incognito was a device of a new diplomacy that dispensed with the accompanying entourage and the one-up-manship it often entailed. Georg Friedrich von Martens, Professor of law at the University of Göttingen, in compiling in 1788 his handbook on laws and customs of European nations wrote that the difficulties arising from the ceremonial «and the enormous expense that it brings on each party have given rise to the custom of traveling incognito» ${ }^{12}$. The creation of the plenipotentiary ambassador or minister was also related to the practice of traveling incognito (see below) ${ }^{13}$. Moreover, by the end of the $17^{\text {th }}$ century, and perhaps earlier, the concept of incognito had migrated beyond diplomacy into a wider literary context but always with a princely reference. By 1700 John Dunton had published a tract on The Art of Living Incognito, even mentioning in passing the example of Peter the Great ${ }^{14}$. Daniel Allen, the year before, in writing about Trinitarians in 1699 assumed his readers would understand the analogy when he wrote that «the most high dwealt in Christ incognito just as some great princes do in foreign courts». «That is, - he said, - though they are personally present, yet they decline those Royal and Princely Honors due to their Character, receiving them only in their Palace Royal» ${ }^{15}$.Other divines referred to the question of whether "Christ's body were substantially present in the sacrament» saying that if so «it would be present so like a Prince in Incognito,

\footnotetext{
${ }^{11}$ Coronelli V. The Royal Almanack... containing a succinct account of the most memorable actions of K. William III... London, 1696; Wing, 2nd ed. A1469B. Pp. 7, 11.

12 von Martens G.F. The Law of Nations: being the Science of National Law, Covenants, Power, etc., founded upon the Treaties and Customs of Modern Nations in Europe (1788), trans. by W. Cobbett, $4^{\text {th }}$ ed. London, 1829. P. 182. Hereafter, Cobbett, Law of Nations. 1789. Precis du droit des gens. Vol. I. P. 214.

${ }^{13}$ Ibid., p. 342.

${ }^{14}$ Dunton J. The art of living incognito being a thousand letters on as many uncommon subjects.... written by J. Dunton during his retreat from the world. London, 1700. Wing D2620.

${ }^{15}$ Allen D. The Moderate Trinitarian. London, 1699. Pp. 31-32.
} 
that he would seem not to require that Honour which we ought to give him under a more public appearance» ${ }^{16}$.

«Incognito» had never been a word unknown to well-read Englishmen. It had had a place in literature in both Latin and Italian texts before its adaptation by the diplomats. Cicero used the Latin word «incognita» ${ }^{17}$ many times to mean «unknown» and at least once in reference to universal wisdom and the pursuit of truth, advising that «we must not treat the unknown as known $»^{18}$. In Ovid's Metamorphosis in the original and in the Renaissance transmission «incognita» is used to convey the idea of «unseen». Shakespeare never used the word, although his plays are filled with incidences of diplomats and disguised identities; neither did Machiavelli even when writing in Italian of the activities of princes [9, p. 138-162]. It is difficult to find examples of common usage of the word through the $14^{\text {th }}$ and $15^{\text {th }}$ centuries in English sources, including translations from Latin and the more common European languages. One is that of John Jewel who, in 1565, kept Erasmus's use of the word «incognito» in paraphrasing St. Paul's speaking of the praise of God in a tongue «unknown» to all thy hearers ${ }^{19}$. It is not, however, until the end of the $16^{\text {th }}$ century that the word «incognito» from the Italian rather than Latin appears in a dictionary in Spanish and English compiled for Richard Perceval by John Minsheu in London, where it is simply defined as «unknown» ${ }^{20}$.

Almost a century later, in 1677, Guy Miege, under-secretary to Charles Howard, Earl of Carlisle and a lexicographer, spoke of one who «lived amongst us unknown or incognito» ${ }^{21}$. That same year, Elisha Coles, in his English dictionary «explaining the difficult terms» added a further dimension to the word, defining «incognito» not only as being «unknown» but also as being «in private» ${ }^{22}$. It was the idea of being «in private,» enmeshed in the concept of «incognito» that made it distinct from other concepts of «disguise» or «impersonation», or «counterfeit.» In the broadest sense Peter could be said to have counterfeited a general naval man, disguised himself and impersonated a soldier, and eventually an Englishman with the "customary dress and wig» but none of these terms explain the rest of his behavior in an ambassadorial context that was part of the very particular protocols of late seventeenth-century diplomacy [6, p. 16]. We shall come back to Peter and «incognito» after a very brief look at other contemporary terms similar to, but quite different from the idea of «incognito» as it was assimilated into the practice and vocabulary of diplomacy.

At the same time that the term «incognito», most broadly meaning «disguised», was becoming fashionable in English and continental usage two other terms with simi-

\footnotetext{
${ }^{16}$ Anonymous. A collection of discourses lately written by some divines.... London, 1687; Wing C5141 (image 199), p. 386.

${ }^{17}$ I.e., incognitus.

${ }^{18}$ De Officiis, vol. I, vi, p. 18. In hoc genere et naturali et honesto duo vitia vitanda sunt, unum, ne incognita pro cognitis habeamus iisque temere assentiamur.... Ed. by W. Miller. Loeb Classical Library. Cambridge, Mass., 1975.

19 Jewel J. A replie unto M. Hardinges answer... London, 1565; Pollard and Redgrave 14606. $2^{\text {nd }}$ ed. O[xord] D[ictionary] of $\mathrm{N}$ [ational] B[iography]. I want to thank Lawrence Manley for this reference.

${ }^{20}$ Percyvall R. [Perceval]. A dictionarie in Spanish and English... all done by J. Minsheu, Professor of languages in London. London, 1599; Pollard and Redgrave, 19620.

${ }^{21}$ Miege G. A New dictionary of French and English with another English and French, according to the Present use... London, 1677; Wing, M2016. Miege accompanied Carlisle to Russia in 1664 and wrote the account of the embassy. See ODNB.

${ }^{22}$ Coles E. younger, An English Dictionary. London, 1676; Wing C5070.
} 
lar, but not identical, meanings-counterfeiting and impersonating-were also in general use. In one way or another they were both related to the idea of disguise. In one sense, counterfeiting meant copying with exact similitude, making a perfect replica of the original but with no intent to deceive. It was a concept critical to the artists of the late Renaissance and early modern period. Early drawings of objects of natural history, shells and insects, for example, were meant to counterfeit the originals, as were the early renderings of botanical specimens. Leonardo da Vinci said, that while the poet «is able to describe forms, actions and places in words», the painter "deals with the actual similitude of the forms in order to represent them.» [18, p. 327]. And it was similar for the writer. In a $16^{\text {th }}$ century sonnet Shakespeare speaks of bearing "your living flowers» rather than "your painted counterfeit» ${ }^{23}$. In portraiture an artist sought to counterfeit a face in drawing the portrait (unless directed otherwise by the sitter who might choose flattery over similitude!) Again, the term is clear in Shakespeare when Richard Plantagenet tells the Duke of Somerset that his «cheeks do counterfeit our roses» ${ }^{24}$. Milton spoke of one «so artful to counterfeit the very shape and visage of Truth» ${ }^{25}$. John White borrowed that concept in writing of his portfolio of drawings of native Roanoke as «pictures of sundry things collected and counterfeited according to the truth [5]». Thomas Blount in his 1661 dictionary still refers to a «counterfeit» as «a draught of an image or picture» rather than a copy or a fake, which was also already widely understood to mean counterfeit ${ }^{26}$.

On the other hand, exactly copying or counterfeiting the King's seal or a piece of currency with the implied intent to deceive was treason. In other words, the intent of the counterfeiter and the object of the counterfeit determined the validity or criminality of the action. By 1541 there was an explicit statute on the books against counterfeiting with evil intent. A person obtaining money or goods by way of a «counterfeit letter or false token» was subject to imprisonment ${ }^{27}$. A pretender or an imposter who wished to conceal his identity was «a counterfeit» in the same way that a false bill was a counterfeit. What, however if one, chose to conceal ones identity and masquerade as another for virtuous reasons as, for example, Tsar Peter? This might be seen as impersonation.

The verb «to impersonate» and the participle «impersonating» describe the scheme of one person taking on the identity of another. While "impersonation» necessitated pretense, that is the deliberate pretending to be another, in dress or in person, or both, the deception was not necessarily malicious in intent. Out of admiration, respect, and desire to emulate one could impersonate a heroic figure or an illustrious character from literature. The story of Martin Guerre first told by Montaigne and later retold by Natalie Davis was one of impersonation. Shakespeare speaks of a

\footnotetext{
${ }^{23}$ Shakespeare W. Sonnets, 16.7-8.

24 Shakespeare W. First Part of HVI, 2.4.62.

25 Milton J. The Reason of Church-Government, 1.831.2; wing M2175.

26 Blount T. Glossographia. London, 1661. Wing B3335.

27 Jacobs G. Law Dictionary, enlarged by G. Ruffhead and J. Morgan. London, 1773. Sub Counterfeit; Statutes of the Realm, 33 H. VIII, c. 1.
} 
«personating» as a «representation» in Timon of Athen ${ }^{28}$. Inherent in the vernacular usage of the term «incognito» was the idea of an impersonal impersonation. That is, that the one who was incognito assumed the dress and name of some impersonal or anonymous character. Ultimately, through this device a royal person, king or tsar, might hope to assume a new character without losing his royal identity, as was the aim of Charles II in escaping the parliamentary forces at Worcester when he impersonated an anonymous woodman by the name of Will Jones ${ }^{29}$. Peter's intent in traveling incognito in Holland as Peter Mikhailov was not to lose his identity as Tsar but to reject the superficial trappings of royalty by temporarily superimposing on himself the character and mannerisms of a common soldier. As Cross noted, «above all, it [the intent] was to be ever vigilant that the honour and status-and other titles-of the Tsar were no way besmirched or belittled» $[6, \mathrm{p} .7]$. The plan was chosen precisely because it allowed him to retain his identity as Tsar while he "Travell'd Incognito in the Retinue of his own Embassy» ${ }^{30}$. D'Auvergne (1660-1737), a military historian, continued his account saying that «The Czar had contriv'd this way of Travelling in the Train of his own Embassy as a private person to see England and Holland, the most flourising and wealthy Countreys in the world...where the most stately, curious and perfect Models for Building of Ships in the World are to be seen...and [where] he has the Sea open to him, in a milder Climate than Archangel $»^{31}$. Note the term "private person», as opposed to a public figure who would be recognizable by his official attire, ceremonial entrance, and retinue. The English Secretaries, however, often did not know how to respond to the idea. Lord Villiers, envoy to Holland at the time, wrote to Edward Nicholas that «The Czar runs about so incognito that nobody knows what to say of him.... ${ }^{32}$.

While «impersonation» necessitated pretense, that is, pretending or feigning to be in the guise of another, being in «disguise» was simply a matter of temporarily refashioning one's external appearance without assuming the identity of any one in particular, whether for good or ill depended on the circumstance. When Sir Henry Wotton, English ambassador to the House of Austria, traveled as a spy to Catholic Rome in 1592, he disguised himself in order to deceive the Italians about his Protestant and English bearings. He wrote that «in order to feign myself an accomodable person... I entered Rome with a mighty blue feather in a black hat which, though it itself were a slight matter, yet surely did it work in the imaginations of men three great effects: First, I was by it taken [to be] no English[man], upon which depended the ground of all; secondly, I was reputed [to be] as light in my mind as in my apparel [and]...thirdly, no man could think that I desired to be unknown who, by wearing that feather took a course to make

\footnotetext{
${ }^{28}$ Shakespeare W. Timon of Athens, 5.1.32.

${ }^{29}$ Blount T. Boscobel: or the Complete History of His Sacred Majesties Most Miraculous Preservation after the Battle of Worcester, 03.09.1651. London, 1660; Wing B3328.

${ }^{30}$ D'Auvergne E. The History of the Campagne in Flanders... and a Summary Account of the Negotiations of the general peace at Ryswick. London, 1698; Wing D297, p. 158-149 [sic].

${ }^{31} \mathrm{lbid}$.

32 Letter from Lord Villiers to Edward Nicholas, 13.08.1697, Surrey History Center, G52/2/19/178. For Edward Villiers, first Earl of Jersey, see ODNB.
} 
myself famous through Rome in a few days ${ }^{33}$. He appeared, then, as a dandy-a far cry from an English Protestant.

The catalyst for the incorporation of the word «incognito» into diplomatic jargon and its expanded definition to include the element of privacy was the Thirty Years War or, more accurately, the peace settlement eventually negotiated at the Congress of Westphalia in 1648. Imperfect and ultimately as impermanent as that peace was, the process of meeting and the drafting of the treaty marked a new departure in diplomatic assemblies and negotiations. The treaty itself ended the wars of religion in the Holy Roman Empire and the eighty years of conflict between the Spanish and the Dutch, formally recognizing the Dutch Republic. Needless to say, the involvement of so many countries in multiple wars demanded a new approach to peacemaking and considerations of universal law. The process began with bringing together in an official capacity representatives of most of the European monarchies, the Dutch Republic, the Holy Roman Empire and the German electors. The peace was to be drafted not in the medieval and $16^{\text {th }}$ century course of full ambassadors with great trains moving back and forth over many months and across hundreds of miles to separate courts and rulers, but, as said above, through extensive negotiations between representatives of the rulers in question. Hugo Grotius (1583-1645) had laid some of the groundwork for the new conception in 1625, twenty-three years earlier. In considering the rights of legations that have their origins in the laws of nations, he concluded that "Ambassadors as if by a kind of fiction are considered to represent those who sent them.» His authority was Cicero who, in speaking of a certain unnamed ambassador, wrote that «He had borne with him the Majesty of the senate and the authority of the state ${ }^{34}$. Here was the origin of the idea of representation that so fascinated another Dutch writer on ambassadors, Abraham de Wicquefort (1606-1682). He described «the representational significance of diplomacy» that «to him symbolized statehood ${ }^{35}$. He underscored the idea "that every public minister is not an Embassador, but that it is necessary he have the Character of Representative». That character came with the authoritative letters of credence from a ruler clarifying that «the Embassador represent the Person of the Prince his Master» ${ }^{36}$. In long and complicated manoeuvers these states organized and sent representatives, 176 ambassadors representing 194 European rulers, to meet and draft a peace that would affect them all. It would be a peace that reflected not the old ius gentium, or law of nations but the new laws between nations, ius inter gentes $[9$, p. 4, 116]. The conference for the process began in 1641 when a resolution was passed by «a mutual agreement and Covenant» in mid December at Hamburg «to make an assembly of plenipotentiary ambassadors who should render themselves at Münster and Osnabrück in Westpha-

\footnotetext{
${ }^{33}$ Smith L.P. The Life and Letters of Sir Henry Wooton. Oxford, 1907. Vol. I. Pp. 272-272.

${ }^{34}$ Philippics. Vol. VIII. P. 23. Cited in Grotius H. The Law of War and Peace, De Jure Belli ac Pacis Libri Tres, Trans. by F.W. Kelsey. New York, 1925. Pp. 438, 443.

${ }^{35}$ Keens-Soper M. «Wicquefort». P. 93. In Berridge G.R., Keens-soper M., and T.G. Otte. Foreign Policy from Machiavelli to Kissinger, Studies in Diplomacy. New York, 2001.

${ }^{36}$ de Wicquefort A. The Ambassador and his Functions. Trans. by J. Digby. London, 1716. Pp. 2, 4.
} 
lia the $11^{\text {th }}$ of July, $\mathrm{N}[\mathrm{ew}] \mathrm{S}\left[\right.$ tyle]...for the space of five years ${ }^{37}$. The Treaty was duly signed five years later in 1648.

The organization for the meetings of so many delegates over a period of several years was complex at every level and geography compounded the complexity. The journey to Westphalia was considerable for most of the participants. Once there, as for a modern conference, housing and meals had to be arranged, and venues for meetings determined. Mail services for the diplomats were essential and a post office was quickly established in Münster ${ }^{38}$. Moreover, beyond the practicalities of living to be worked out were the protocols of international communication--the rankings of diplomats and their secretaries, and the means whereby their first formal introductions and meetings would take place. Needless to say, translators and linguists were imperative at every juncture. Preliminary to their arrival titles, ranks, and precedency of the participants had to be agreed to by all the parties involved. Designating the ranks of the representative diplomats--ambassadors, plenipotentiaries, extraordinary deputies, electors, princes and states of the Sacred Roman Empire-and defining the parameters around which they would assemble and negotiate was a large task for which there was little precedent. François Callières (1645-1717), an ambassador Extraordinary and Plenipotentiary at a later assembly at Ryswick, made the point in his contemporary treatise on diplomacy, that when a peace conference was to meet it required enormous preparation beforehand. "In a certain sense», he said, "the embassy itself should be a reproduction in miniature of the whole diplomatic service.» He ranked the diplomats hierarchically as (1) ambassadors, (2), envoys extraordinary, (3) residents, (4) secretaries, and (5) agents. ${ }^{39}$ Having made that point, however, Callières was more interested in the theory of «the good negotiator» and the demeanor of the ambassador than in the details and practicalities of the day-to-day meeting of a large diplomatic conference. He emphasized that the «negotiator of our time» must be acquainted with all of the agreements of the European powers beginning with the Treaty of Westphalia» $»^{40}$.

The idea of incognito was a small procedural detail not mentioned in Cailliéres's broader treatise, in part because being incognito did not signify rank but described bearing. It was a procedural tag outside of the substantive issues he was addressing. Many ambassadors and envoys, however, were incognito at the congresses in question and some of those ambassadors had come to be called plenipotentiaries. In conclusion Calliéres, however, added that the «title of plenipotentiary is sometimes given as well to ambassadors[,] according to the occasion ${ }^{41}$. Plenipotentiary was a new designation to signify not a particular rank in the diplomatic service, but to denote one with full

\footnotetext{
${ }^{37}$ For a list of the signators of the Resolution in Hamburg, see The Articles of the Treaty of Peace, signed and Sealed at Munster, in Westphalia, 24.10.1648. London, 1697. P. 3.

${ }^{38}$ Henning. Russia and Courtly Europe. Pp. 88-89.

${ }^{39}$ Callières F. On the Manner of Negotiating with Princes; on the Uses of Diplomacy; the Choice of Ministers and Envoys; and the Personal Qualities necessary for Success in Missions abroad. Paris, 1716. Trans. from the French by A.F. Whyte. Boston, 1919. P. 71. His rankings did not include Russia. See Henning, Russia and Courtly Europe, pp. 104-106.

40 lbid., p. 42.

${ }^{41}$ Ibid., p. 73.
} 
authoritative power to negotiate on behalf of his sovereign ${ }^{42}$. In Wicquefort's words "The Quality of Plenipotentiary does not give a new Character to a minister; it only denotes the extent of his Power and Authority». And he went on to say that «the title is become so common since the Assembly at Münster [1643], that it can no longer be refus'd to those whom the Sovereign has cloth'd with the character of Embassdor» ${ }^{43}$. The Westphalian peace itself was signed by «plenipotentiaries and ambassadors» before being ratified by the rulers ${ }^{44}$. This distinction of the plenipotentiaries is important to the understanding of the protocols surrounding the practice of being incognito. A minister or ambassador plenipotentiary, as one incognito, did not require the entourage that was requisite for an ambassador special, residential, or extraordinary.

With regard to plenipotentiaries, there was still fluidity to their rank at the assembly at Nijmegen (see below). It was reported by Sir Leoline Jenkins, English ambassador at Nijmegen in March 1676-7 «that the Imperial Ministers at Munster were no more but plenipotentiaries, not ambassadors; and yet their treatment was in all things like that of ambassadors.... ${ }^{45}$. However, as with all changes, the parameters of the title took time to settle and in 1716 Callièrs could still write that «Il y a des Negociateurs qui ont voulu introduire un nouveau caractere entre celui d'Ambassadeur \& celui d'envoyé, les uns sous le titre de commissaire-plenipotentiary ${ }^{46}$. By the end of the century the reference was generally to an «ambassador plenipotentiary» or a «plenipotentiary ambassador». Eventually, however, even that would change. Martens wrote later that it was «now the custom, in order to avoid disputes with respect to the ceremonial, to give the ministers who are sent to congresses, the title of plenipotentiary only, and not that of ambassador ${ }^{47}$. The office of plenipotentiary, however, regardless of the holder's title, was similar to an envoy incognito in the sense that both could and did travel without a train or entourage but were fully identified as bona fides representatives of a foreign power.

The arrangements drafted by the congress for the Peace of Westphalia provided the guidelines for subsequent multi-national European assemblies. Throughout the latter half of the $17^{\text {th }}$ century following Westphalia large assemblies of diplomats convened to draft treaties of peace and to establish more permanent state boundaries. One met at Breda in 1667, another at Aix-la-Chapelle in 1668, one in Cologne in 1673, and one in Nijmegen from 1675 to1679. Out of them came more refinements of old and some new forms, titles, and protocols, and it was at these congresses that the notion of «incognito» was further honed and shaped to fit the new diplomacy. Envoys incognito of every rank attended them all. And from these the idea of being incognito became more universally understood. When William III returned to the Hague from England, for example, in

\footnotetext{
${ }^{42}$ Lachs P.S. The Diplomatic Corps under Charles II and James II. New Brunswick, 1965. P. 5.

${ }^{43}$ Wicquefort. The Ambassador, p. 42; Calliéres. On the Manner of Negotiating with Princes. P. 42.

${ }^{44}$ Anon., Articles... 1648. Wing A3876A. P. 3. The book contains The Articles of the Treaty of Peace at Munster, Westphalia and the Treaty of Peace between France and Spain at Nijmegen.

${ }^{45}$ [William Wynne]. The Life of Leoline Jenkins... Ambassador and Plenipotentiary for the General Peace at Cologn and Nimeguen, compiled by William Wynne. In 2 vols. London, 1724. Vol. II. P. 71. Jenkins was a representative at Cologne 1673, and Nijmegen 1676-1679, later Secretary of State. ODNB.

${ }^{46}$ de Callières F. De la maniere de Negocier avec Soverains. Amsterdam, 1716. P. 33.

${ }^{47}$ See Cobbett. Law of Nations. P. 342.
} 
1690, it was reported in general newsletters that the Elector of Brandenburg was there at the fireworks incognito, and it was also reported that William himself, Stadtholder and King, «entered the Hague privately, and yesterday made his public entrance» ${ }^{48}$.

Almost twenty years after Westphalia, at Breda, in May 1667, ambassadors from France, Denmark, the States General of the United Provinces, and England convened to negotiate peace between England and Holland, ending the second Anglo Dutch war (1665-1667). The peace ensured that in North America France would keep Acadia; the English would retain the colonies of New York, New Jersey, Pennsylvania and Delaware, while the Dutch would keep Surinam. From London, the Right Honorable the Lord Holles, ambassador extraordinary from Charles II, and the Lord Coventry, plenipotentiary, arrived by ship to attend the conference ${ }^{49}$. After embarking they were first taken to a small fort near the town where they spent the night. There, one of the French ambassadors, Monsieur Courtin, «came himself to them incognito» in order «to give their excellencies a visit» informally. Following that visit Lord Coventry was dispatched incognito to the town of Breda itself. That is, he went, as the French ambassador had come to him, privately, in his own name, as plenipotentiary, without a train and without his own coach and retinue (all of which were still on the ship that had brought him to Holland), and before he had had any formal audience in Holland. Four days later the English Lords and all of the other national envoys that had arrived for the assembly went incognito to a park outside of town. There, Sir George Charnock, the Knight Martial [sic] of the United Provinces, explained the order of the public procession he had drawn up for the formal entry of all of the delegates into the town of Breda. For this first public and ceremonial entry the Knight Martial carried the gilded Baton or Staff of office and the Ensign. He was followed by the Lords Holles and Coventry in the first coach which, with the "furniture of the horses» and all was «exceeding rich and royal». Other coaches followed to the town where there was «the greatest state and splendor of the Solemnitie: during the whole time of which great Guns from all sides of the town were liberally discharged.» On several days following this dramatic entrance the ambassadors from France and Sweden, whose visit was incognito, they «having not yet made their publique Entri,» and the burgomaster of the town gave visits to the English, with their entourages, to the English. Thereafter «there was a discontinuance of all ceremony «and very few visits were made» while the delegates settled down to meet daily for negotiation ${ }^{50}$.

From the ambassadorial and state reports from Westphalia and Breda the difference between public and private meetings becomes clear. «Incognito» in these reports, meant «in private», without an entourage, or, sometimes, in secret, as was the case of Peter's later meeting with William at Utrecht (below) [6, p. 9 ${ }^{51}$. With the diplomats disguise was not an issue. In the case where an ambassador was incognito, he was an

\footnotetext{
48 J.D. A True and full relation of his Majesty's safe arrival and reception at the Hague. London, 1690, Wing D45A, Pp. 1-2.

${ }^{49}$ Anon. [a person of quality concerned in this embassy], A narrative or Journal of the proceedings of their Excellencies, the Right Honourable the Lord Holles and the Lord Coventry appointed by his Majesty of Great Britain to be his ambassadors extraordinary and plenipotentiaries for the Treaty held at Breda... London, 1667. Wing N230. Pp. 8-11.

${ }^{50}$ Ibid., p. 16.

51 Price. Adventure to Russia. P. 25.
} 
ambassador impersonating a private person without having relinquished the authority and representative aspect of his title and office. Generally his appearance incognito would precede his formal introduction as ambassador. On the other hand, even after that formality, an envoy traveling without an entourage was labeled incognito. When this stratagem was adopted by the Tsar traveling privately as the soldier Mikhailov, or as the navy man in the dock yards, it «fooled no one but was devised to allow Peter a degree of freedom of behaviour and movement which he could not otherwise have enjoyed» $[6, \mathrm{p} .7]$. That is, he was bound by no customary ceremonial protocols and, indeed, by the rules of the game could not participate in them.

After the meetings at Breda Sir William Temple traveled incognito through Holland privately with a tiny staff on the way to taking up his position as English ambassador at the Hague. In a letter to his brother, October 10,1667, he expressed precisely the experience that we can imagine Peter hoped to emulate thirty years later. Temple described the great pleasure he found in the journey through Holland to Amsterdam in observing «the strange freedom that all men took in boats, and inns, and all other common places, of talking openly whatever they thought upon all the public affairs both of their own state and their neighbors, and thus», he continued, «I had the advantage of finding the more by being incognito, and think it the greatest piece of the liberty that country so much values $»^{52}$. Is Temple perhaps suggesting that the idea of traveling privately, without an entourage, had its origins in the Republican Netherlands? (An idea for Dutch scholars to further explore?). On his arrival in the Hague he was pleased that the Master of ceremonies invited him «if [he] desired, to remain any time incognito» in the town before his official entry or introduction was made ${ }^{53}$. C. W., the unidentified author of a pamphlet on the Congress at the Hague, in 1691 wrote in reference to the two electors of Bavaria and Brandenburg that «it seems William the Third had set them a Pattern. They came to Consult, to Act, and not to show their Grandeur. No publick Entrances were made, they all arrived incognito», with assumed names, «and they were imitated by the rest of the Princes $»^{54}$. Temple would later be nominated to attend the Congress at Nijmegen.

The negotiations for what would result in the Treaties of Nijmegen began in 1673 in Cologne. Later, during the summer and autumn of 1675 the full assembly of ambassadors and envoys plenipotentiary gathered in Nijmegen to begin drafting articles for the peace treaties that would be signed in 1678 and 1679 between France, the Dutch Republic, Spain, Brandenburg, Sweden, the Holy Roman Empire, and the Prince-Bishopric of Münster. Once again, as with the earlier assemblies, there was at the outset in Nijmegen the need for the organization of living and working arrangements. In the first days of the congress a trip to the Stadt-House was undertaken by Beverning, one of the Dutch delegates, and the English envoy, Sir Leoline Jenkins, «to see what may be fit or altered

\footnotetext{
${ }^{52}$ [Sir William Temple]. Memoirs of the Life, Works, and Correspondence of Sir William Temple, Bart. Ed. by T. Peregrine Courtenay. In 2 vols. London, 1836, Vol. I. P. 116. On the matter of freedom in the Republic, see J. Israel. The Dutch Republic, Its Rise, Greatness, and Fall 1477-1806. Oxford, 1995. Pp. 677-699.

53 [Sir William Temple]. Memoirs. Vol. II. P. 283.

${ }^{54}$ C.W. The Congress at the Hague. London, 1691; Wing C5843. P. 21.
} 
there for the better conveniences of the Assembly in their Conferences $»^{55}$. They agreed that the building would afford «several good rooms, as good or better than those of the Carmes at Cologne» ${ }^{56}$.

For most of the representatives the journey to Nijmegen itself was considerable and often, as for earlier meetings at Breda and Cologne, the carriages and baggage of the diplomats were brought up to the town later. On arrival, then, they met with their counterparts incognito \& par amitié, that is to say privately and in friendship rather than publicly and formally. The English described one such visit from the French as «en amy» «because there was a kind of negligence in the Equipage» and there were not the number prescribed by an embassy but only « 2 Footmen by the Side of an old Coach, the new coaches to arrive with the rest of the baggage ${ }^{57}$. The French ambassadors were said to be «incognito, and without Train, having left almost all their servants in the Boats with the rest of their goods, which did not arrive till next day ${ }^{58}$. Shortly thereafter, when all the baggage had arrived, they were formally visited by Jenkins, Lord Ambassador from England, in a coach with six horses. The Dutch and French ambassadors then repeated the courtesy «so soon as their Train and Equipage were in a condition to appear abroad $\aleph^{59}$. Later in the autumn Lord Barclay, the Chief of the Mediators, who had been the English ambassador extraordinary in France, came with his wife and after some days being there incognito gave notice of his arrival. Although many did not come until the beginning of the new year, in the course of the autumn protocols for the first visits and introductions were arranged according to the direction of the French. Most of the delegates believed they were to operate as they had earlier, in the style of incognito \& par amitie, but that apparently that was not the case. The English diplomats reported at the beginning of January that Count Kinsky, the Imperial Ambassador, was told that «there was no Prince or Court to apply to, or appear in, in this place, and consequently those styles of Cognito and Incognito [would] not be followed». In other words, all meetings would be informal. That, however, it appears, was his own interpretation. Don Pedro de Ronquello of Spain coming from England where he had been Envoy Extraordinary «stayed still at the Hague expecting the rest of his equipage from England, but being at length in Nimueguen continued long incognito» and it was reported that he remained so above a month ${ }^{60}$. At the end of January apparently protocols were still not finally agreed on and Jenkins reported that «we spent the greatest part of the day yesterday in endeavoring to reconcile these niceties ${ }^{61}$.

Being incognito in the the small town of Nijmegen had its advantages in simplifying getting around, particularly where the narrow streets made coach traffic difficult. We see this in the example of the Nuncio sent by Pope Innocent XI who was first visited by

\footnotetext{
${ }^{55}$ Wynne. Leoline, Jenkins. Vol. II. Pp. 411-412.

${ }^{56} \mathrm{lbid}$.

57 Ibid. Vol. I. P. 370.

${ }^{58}$ Luc Courchetet d'Esnans. This History of the treaty at Nimueguen...., translated out of the French. London, 1681; Wing H2187. P. 5.

59 lbid. P. 6.

${ }^{60}$ lbid. Pp. 80-81.

${ }^{61}$ Wynne. Leoline Jenkins. Vol. II. P. 37.
} 
the three ambassadors of France «who went severally to visit the nuncio incognito and on foot, his house being distant but a few steps... [and] the Emperor's ambassadors were there also in the morning incognito» ${ }^{62}$.

Obviously, the ease of movement without coaches and an entourage was liberating for the delegates and, perhaps of more importance, cost saving for the states ${ }^{63}$. It seems, too, that the envoys liked the arrangement that was quickly becoming precedent. On count Anthony of Oldenburg's coming to Nijmegen «he gave no notice of his arrival, gave nor received no Visit and continued still incognito at Nimueguen;» but that, he said, «hindered [him] not but that he met at conferences and especially at all places where they played $»^{64}$. Clearly functionality was more important here than ceremonialprecisely Peter's contention regarding the business of governments.

The reports on Nijmegen and the earlier assemblies, were well circulated throughout the countries of Europe. News traveled fast by way of gazettes and newsletters as well as by merchants and traveling artisans. Tsar Peter had only to converse with his ambassadors who were au courant with European protocols to understand what was requisite in embassies of various sorts $[7, \text { p. } 77-79 ; 10, \text { p. } 101]^{65}$. Dmitry Fedosov, a modern historian, tells us that Patrick Gordon, Peter's close friend and confidant at home in Moscow, was one of those through whom he became acquainted with the customs of Western Europe and that Gordon had «first-hand practical knowledge of European courtly protocol ${ }^{66}$. No one did more, Fedosov said, «to turn Peter's eyes and aspirations toward the west,» and Paul Bushkovitch relates Gordon's new intimacy with Peter's household after $1688^{67}$. It is also worth noting here that this was the same Patrick Gordon who over the previous two decades had supplied the London Gazette with news of Russia $[6, \text { p. } 5 ; 8]^{68}$. This said, however, it does not explain precisely the source of Peter's information about traveling incognito. Perhaps a closer reading of his papers in the Russian archives would be revealing. From other sources we know Peter's interests in the world outside of Russia were personal as well as national. As one historian has written, his embassy's mission «was to acquire and transfer the technological know-how of the West to Muscovy» through «the formidable tsar's curiosity and wish to learn» [1, p. 18]. Aside from seeking European and English alliances against the Turks, he wanted to see the countries with whom Russia had connections and meet his ruling counterparts in the Netherlands and England, to understand how foreign governments worked in all departments, particularly those related to the Navy and ships and shipbuilding.

\footnotetext{
62 lbid. Pp. 60-61.

${ }^{63}$ The other major cost-saving component of the Congresses was that as no royalty were present gifts were unnecessary.

${ }^{64}$ Courchetet d'Esnans. Nimueguen. P. 80.

${ }^{65}$ Russia had been involved peripherally in the Thirty Years' War through her conflict with Poland over Smolensk in the 1630 's but did not send diplomats to Münster or Osnabrück.

${ }^{66}$ Fedosov D. Diary of General Patrick Gordon of Auchleuchries, 1635-1695. In 6 vols. Aberdeen, 2009-2016. Vol. VI. P. xiii. Vol. V. XI. P. 306. It was Gordon who, on 31.07.1694, at the Tsar's request translated the first Russian code of navy signals for the use of British Captains.

${ }^{67}$ Bushkovitch P. Patrick Gordon and Russian Court Politics // Journal of Irish and Scottish Studies. 2010. Vol. 3. Iss. 2. Aberdeen, 2010. P. 11.

${ }^{68}$ Regarding the validity of the Gazette and newspaper accounts of the embassy.
} 
Peter, then, knew that traveling as the Tsar incognito would have no affect on the authority of his position; he understood the protocol. It was a new experience, however, for the English, and even the Germans along the way, to have the ruler of a sovereign state appear in disguise as a private person all the time retaining his official titles and authority. Let us turn again to the embassy and look briefly at how the English handled this.

As we have said, spring was just making its first appearance when the Grand Embassy left Russia in 1697. It was written in a letter from Germany to Sir William Trumbull at the Hague in mid-June, that «you will hardly believe the Czar is reported to be at Konigsberg incognito...he lives as he pleases and sleeps on a yacht of the electors on the river, keeping up his incognito except when he is with my masters ${ }^{69}$. Aside from sleeping on a boat he may also have not used a chair. The report of one ambassador incognito indicated that the simple formality of using a chair must be refused. In that case two cushions were provided for the ambassador «for his legs were not so plyable in sitting Taylor-wise like the rest, yet he would not use a chair, though one offered him, him being then incognito» ${ }^{70}$. After his arrival in Holland, in his introductory speech to William in September 1697, Peter said that «it was the vehement passion alone of seeing the most Brave and most Generous hero of the age.» that brought him to Holland $[1, \text { p.5; 6, p. 9-10 }]^{71}$. And those were no empty words. In Moscow, having heard of the event, Peter had fired a salute in honor of William's military victory at the Battle of the Boyne [4, p. 175, n. 14]. Meanwhile, for the present, Peter left the negotiations of his embassy regarding finance and trade to be handled by the ambassadors themselves, whose job it was to be formally and ceremonially introduced and then to spend time speaking and translating, all with which they had had experience. In early October 1697 at the first audience with the States of the United Province the Tsar "was in an adjoining chamber...whither he was come privately and was as secretly conveyed out again.... ${ }^{72}$. The same day the English made a formal and public visit to the Russian ambassadors with each English envoy having 2 coaches and 6 horses ${ }^{73}$. All the while the Dutch were fascinated by Peter, and the English Secretary of State, Sir Joseph Williamson, reported from the Hague that it was not known where they [the Russians] would go next but, he said, «it may be scarce known to themselves so romantic an humour is it that possesses that Prince» ${ }^{74}$.

Rumors circulated about the Tsar, however, and Narcissus Luttrell wrote as early as 29 July 1697 that "tis believed he [Peter] will accompany his Majesty to England» ${ }^{75}$. The news was repeated in November, and he finally set sail in early January from Helvort Sluys on the King's yacht, arriving in London a few days later, the North Sea crossing

\footnotetext{
${ }^{69}$ HMC, Downshire. Pt. I. Vol. II. P. 746; BL Add. 22031, ff. 17v-19, Blaythwayt Journal.

${ }^{70}$ Burbury J. A Relation of a Journey of the Right Honourable My Lord Henry Howard from London to Vienna... London, 1671; Wing 5611. P. 182.

${ }^{71}$ Luttrell N. A Brief Historical Relation of State Affairs from September 1678 to April 1714. In 6 vols. Oxford, 1857. Vol. IV. P. 29.

72 BL Add. 28900, f. 103, letter 08.10.1697 to J. Ellies, Under Secretary of State at Whitehall from Sir J. Williamson.

${ }^{73}$ lbid.

${ }^{74}$ BL Add. 28900, f. 82, 27.09.1697 to J. Ellis, Under Secretary of State.

${ }^{75}$ Luttrell. Historical Relation. Vol. IV. P. 258.
} 
paid for by the English crown ${ }^{76}$. By order of the Admiralty, 28 January 1697, it was resolved that Vice Admiral Mitchell be paid one hundred pounds by the Admiralty Office «for his charges in attending the Czar of Moscovy over from Holland ${ }^{77}$. At the outset a private newsletter writer, John Biscoe, reported that on Peter's arrival it was said that he would «stand incognito in the city to see his ambassadors make their public entry through the City ${ }^{78}$. His desire for privacy, to see and not be seen, to be tied to no calendar of state dinners and court formalities, was underscored at every juncture. King William, understanding the protocol himself, in turn had «been 3 times incognito to see the Czar» ${ }^{79}$. On one occasion William had visited Peter «entirely incognito and, indeed, in the coach of Count Romney» ${ }^{80}$. It was a comfortable arrangement for them; a clear advantage for both Peter and William being incognito was language. Without the trappings of formality they could converse together in Dutch on a multitude of topics. Peter knew no English, and William no Russian but they both knew Dutch. The Austrian ambassador even reported that to the King's spoken Dutch Peter's «answers almost every time preceded the translator, a sign that he understands the language rather well» $[17, \text { c. } 239-244]^{81}$. It should be noted here, too, that Peter, in keeping incognito, spoke a vernacular Russian with members of the Muscovy Company. On learning this, the Austrian ambassador wrote to Emperor Leopold that Peter, when conversing in Russian with members of the Company, spoke «according to his normal manner of speech (as if he were not, in fact, the Tsar himself») ${ }^{82}$. He further reported that for a meeting in Kensington Palace the Tsar wore «muscovite dress» and «neither the guard nor anyone else took notice of him, since nobody knew anything about the visit» which, of course, had been in private ${ }^{83}$. The reports were important because on leaving Holland Peter would return to Russia by way of the Court at Vienna, where he also appeared incognito [10, p. 160-187].

From the accounts of Peter's stay in London we learn that on 21 January, a Mr. Burton from the Lord Chamberlain's office, came to Peter wishing "to attach some attendant of the King's [to the Tsar's party] who could at all times report the latter's wishes to His Royal Highness». It was decided that the best person for this was the Vice Admial Mitchell because of his command of Dutch ${ }^{84}$. Later Mitchell came to Peter «and declared that his Royal Majesty had ordered him, the Vice Admiral, to be permanently in waiting on his Czarish Majesty and to show him every service and to report all his Czarish Majesty's wishes to his Royal Majesty».

\footnotetext{
${ }^{76}$ BL Add. 28900, f. 386, letter from the Hague 21/11 January to J. Ellis, Under Secretary of State, from Sir J. Williamson.

${ }^{77} \mathrm{~N}$ [ational] A[rchives], ADM 3/285, ff. 65-66. The arrangements for the travel had been made in mid-December. See CSPD William III. 1697. P. 518.

${ }^{78}$ BRBML, Yale University, OSB MSS fc 163, box 1, manuscript newsletter of J. Biscoe, 01.01.1697/8, to the Maunsell family.

${ }^{79}$ Luttrell. Historical Relation. P. 340.

${ }^{80}$ Newsletter 14/28.01. to Sir J. Williamson. CSPD William III. 1698. Pp. 28-29(2).

${ }^{81}$ From the account of the Austrian ambassador, taken from A. Gaedeke, «Peter der Grosse in England im Jahre 1698. Im neuen Reich. Bd. 2 Jan.-June 1872. Pp. 217-224. Transl. by Prof. P. Bushkovitch, 25.01./04.02.

${ }^{82}$ Ibid., 25.02./07.03.

83 lbid.

${ }^{84}$ Dixon S., et al., Britain and Russia. No. 38. Pp. 21-22.
} 
William would spare no expense in satisfying Peter. A defining dimension of the Tsar's identity while incognito in England is identifiable in all of the Crown records where Peter was always titled «Tsar». Indeed the repercussions of the arrangement for the English were primarily financial as they might have been for any visiting royalty ${ }^{85}$. While many of Peter's incidental expenses were paid by Andrew Stiles and later reimbursed by the Russian government, the larger costs of food, lodging, and transport were paid by the English government ${ }^{86}$. And, at the time it was somewhat a strain on the Treasury remembering that Whitehall had burned the week Peter arrived in London and the clean-up for that was substantial and noted in all of the Treasury books. The financial accounts for Peter were begun on 29 December 1697 when the Treasury Chamber at Whitehall passed an order for 1,500 pounds «in lottery tickets to be issued to the Cofferer of the Household [Francis Newport, Earl of Bradford] to provide for the reception of the Czar of Muscovy and his train ${ }^{87}$. (His train being only those few who accompanied him to England, the others remained in Holland.) The money was to be raised through the malt lottery. On the same day as the order from the Treasury Chamber the Auditor of Receipt was to issue «15,000 li. to the Cofferer of the Household...to be issued out of malt lottery tickets...intended to provide for the reception of the Czar of Moscovy» ${ }^{88}$. In early January Sir George Fletcher wrote to his friend, letter-writer and antiquary, Sir Daniel Fleming, that «the Czar is highly caressed by the King but he keeps still incognito» ${ }^{89}$.

The events of Peter's stay in England are well known. I mention here only several points that underscore the official maintenance of his title of Tsar even as he lived privately incognito and sometimes in disguise, or at least costumed in clothes other than royal attire.

On his arrival in London on 10 January 1698 Peter stayed originally in a house near the Strand, on Norfolk Street where he lay «incognito.» facing the water side $e^{90}$. It was reported to Sir Joseph Williamson on 14 January that «the Czar of Muscovy continues very private....The King's officers attend him at present, but he will not suffer them to treat him with any manner of ceremony». On 9 February he and his small train moved down river to be near the dockyards «amongst the ships' carpenters $»^{92}$. Thereafter he was lodged in John Evelyn's house in Deptford that had been sublet by John Benbow, Vice-Admiral, and then prepared for Peter and his company. When the Russians left, Evelyn was recompensed for the «damage done to his house, goods, and gardens at Deptford by his Czarish Majesty and his retinue while they resided there according

\footnotetext{
${ }^{85}$ Christian IV of Denmark, in 1606, was the only visiting monarch to England before Peter.

${ }^{86}$ For an account of reimbursements to the merchant, Stiles A., for support of Peter I in England, see Dixon S., et al. No. 19. Pp. 16-17. The account is from RGADA. F. 196. Sobranie Mazurina. Op. 3. No. 195. Vol. II.

${ }^{87}$ From the Treasury Minute Book. Vol. X. Pp. 81-3. Printed in the Calendar of Treasury Books, October 1697 to August 1698. London, 1933. Vol. XIII. P. 49.

${ }^{88}$ From the Disposition Book. Vol. XIV. P. 145. Printed in Ibid. P. 208. By Statue, 8-9 William III. C. 22. Malt was a 1,400,000 lottery on malt duties at 10 li. tickets.

${ }^{89}$ HMC. Twelfth Report. App. VII. P. 349.

${ }^{90}$ CSPD William III. 1698. P. 24; Luttrell. Historical Relation. P. 330.

91 Ibid. P. 28.

92 Luttrell. Historical Relation. P. 340.
} 
to the estimation of Sir Christopher Wren...allowed by virtue of a warrant from the Lords Commissioners of his Majesty's Treasury dated the xxi of June $1698 »^{93}$. Benbow was also compensated for the damages done to his goods and also «more to him for xiiii weeks rent of this house xxv li»»" Moreover, one Russell was reimbursed for the damage done to the small adjoining house where the guards were kept ${ }^{95}$. In a small digression here it is interesting to note, however, that not all of the repairs were from damage done by the Russians. According to a letter to the Admiralty from the Clerk of the Council, William Bridgeman, when Peter first took Benbow's house there was «some part of the path very rotten» which the Czar desired might «be made good with ballast». The Secretary wrote that he believed «it may take up about twenty tuns to do the same» but that it was by direction of the Lords of the Admiralty that such things be attended to and that «the same be layd by some of our laborers» ${ }^{96}$. The walkway in question was probably that leading down to the dockyards where Peter planned to spend his days.

For his interest in ships and shipyards Peter was to have complete freedom to observe and study all aspects of the business of the dockyards. A great deal has been written about Peter's time spent in Deptford and about the King's gift of the Royall Transport $[6, \text { p. 3 }]^{97}$. It was a royal gift in all senses of the word. The yacht had been ordered for the "Czar of Muscovy». In presenting it William was formally and publicly recognizing the title and authority of Tsar Peter while at the same time accepting his guise of incognito and the fiction of Peter the dockyard worker as a legitimate diplomatic protocol.

It was on 1 March 1698, that Sir George Rooke signified to the Admiralty Board that «it was his Majesty's pleasure that ye Royall Transport should be forthwith delivered to ye Czar of Muscovy as a present from his Majesty and, that such alterations and accommodations should be made in her as ye Czar should require» ${ }^{98}$. Moreover, to complete the gift it was ordered by the Admiralty Office on 7 March that the Royall Transport was to be «victualled for one hundred men at whole allowance till the 15 of June next,» that was, for the remaining time of Peter's stay in England ${ }^{99}$. When the yacht was finally rigged and ready to sail a proportion of sea stores was also prepared for her ${ }^{100}$. The Board took special care that she be furnished as a ship for foreign voyages rather than simply coastal navigation ${ }^{101}$. And, it was reiterated by the Admiralty Office that as «his Majesty having made a present of her to him,» that therefore the yacht was to be

\footnotetext{
${ }_{93} \mathrm{NA}, \mathrm{E} 351 / 3310$. Works and Buildings, 01.04. to 31.03.1699. Evelyn wrote that «l went to Deptford to view how miserably the Tzar of Muscovy had left my house after 3 monthes making it his court.» The Diary of John Evelyn. Ed. by E.S. de Beer. London, 1959. P. 1025.

${ }^{94} \mathrm{NA}, \mathrm{E} 351 / 3310$. Works and Buildings. 01.04. to 31.03.1699.

${ }^{95}$ Ibid.

${ }^{96}$ NA, ADM 106/516/300. Pt. 2. 12.02.1697.

${ }_{97}$ See also CSPD William III. 1697. Pp. 413-414. 05.10.1697, minutes of the Lords Justices «signifying the King's intention of making a present of the Royal Transport to the Czar»; BL Add. 40778, W.Blathwayt's letter book, f. 96v; NA, ADM $106 / 516 / 312$, even the paint was to be the choice of the Tsar.

${ }^{98}$ Ibid., ff. $77 \mathrm{v}$.

${ }^{99} \mathrm{NA}, \mathrm{ADM} 3 / 285$, f. 80.

100 NA, ADM 106/516/300. No. 303, 306.

101 Ibid., no. 306.
} 
delivered «accordingly by inventory.» i.e., officially, through all offices of the Admiralty and Treasury ${ }^{102}$.

The gift was then topped off by a resolution «in pursuance of his Majesty's pleasure» that an English convoy be ordered to see her as far as Archangel, if furnished with proper pilots». Otherwise they would take her to the North Cape. The Board also made provision to pay for the pilot at Flamborough ${ }^{103}$. For Peter's return to Holland it was Captain Wright who was ordered to prepare the expedition yacht ${ }^{104}$.

With this brief note on the Tsar's leave-taking from England I am brought again to Sir William Temple who recalled in his memoirs, that while English ambassador at the Hague he was compelled «to assume all the stiffness and grandeur of the King's immediate representative». Shortly after, following a particularly contentious moment at court he wrote that, «This I am sure of, that if I have not leave to skulk up and down incognito I shall never be able to do my business and live my own life» ${ }^{105}$. Peter, too, required time unencumbered by stiffness and grandeur to digest what he had learned and contemplate his role in building the Russian state.

What becomes clear in the conclusion to Peter's story is that the pattern of his incognito travel provides us with a legitimate example of conduct derived from a new diplomatic protocol of the late $17^{\text {th }}$ century. With a rare clarity of vision Peter adopted that protocol to forward his own objectives. By exercising a Tsar's prerogative of choice he traveled incognito, publicly rejecting the old formalities of the traditional royal entourage and the patterns of monarchy that accompanied it in order to embrace the new freedom of movement legitimized for envoys at the first intra-European congress assembled for negotiating the Peace of Westphalia.

The general re-working of ambassadorial titles and practices in the seventeenthcentury prepared the way for a more settled pattern of diplomacy in the eighteenth. By then plenipotentiary ministers were well established as representative and authoritative diplomats, and royalty could travel as it chose. The practice of ambassadors and sometimes royalty, as in the cases of Peter and William III, traveling incognito had occupied a moment in time captured in the transition from the formal ceremonial relations of personal monarchy to the idea of the representation of the sovereign state by a regular corps of ambassadors and plenipotentiary ministers ${ }^{106}$. In this case, it was the monarchs themselves who marked the transition.

\footnotetext{
102 Ibid., f. 83.

103 NA, ADM 3/14, 06.04., no f. no.

104 Ibid., 18.04.

105 [Sir William Temple]. Memoirs. Ed. by T. P. Courtenay.

106 On his return from the continent in 1699 Peter followed the same diplomatic protocols in Moscow when he chose. J. Deane, shipbuilder, in a letter to the Marquess of Carmarthen wrote on 08.03.1699, that on the 25.08. last his Majesty came to Moscow incognito [and] immediately he took in hand the rewarding of [Patrick] Gordon's soldiers that fought against the rebels.» J. Dean. A letter from Moscow to the Marquess of Carmarthen. London, 1699; Wing D498B. P. 1.
} 


\section{References}

1. Barany G. The Anglo-Russian Entente Cordiale of 1697-1698: Peter I and William III at Utrecht. New York, Eastern European Monographs Publ., 1986. $101 \mathrm{p}$.

2. Berridge G.R., Keens-soper M., Otte T.G. Diplomatic Theory from Machiavelli to Kissinger, Studies in Diplomacy. Palgrave Macmillan Publ., 2001. 216 p. DOI: $10.1057 / 9780230508309$

3. Bushkovitch P. Patrick Gordon and Russian Court Politics. Journal of Irish and Scottish Studies, 2010, vol. 3, iss. 2, p. 11.

4. Bushkovitch P. Peter the Great, The Struggle for Power, 1671-1725. Cambridge, England Publ., 2001. $187 \mathrm{p}$.

5. Chaplin J.E. Roanoke 'Counterfeited According to the Truth'. A New World, England's first view of America. Ed. by K.Sloan. Chapel Hill Publ., 2007. Pp. 51-63.

6. Cross A. Peter the Great through British Eyes, Perceptions and Representations of the Tsar since 1698. London, Cambridge University Press Publ., 2001. 208 p.

7. Dukes P., Graeme P. Herd, and Kotilaine J. Stuarts and Romanovs, the Rise of a Special Relationship. Dundee, Discovery Press Publ., 2009. 256 p.

8. Gouzevitch D. et I. La Représentation of the Grande Ambassason de Pierre Ier (1697-1698) dans les journaux: la presse comme source pour les recherches historique. E-Journal of Eighteenth-Century Russian Studies, 2016, no. IV, pp. 24-31.

9. Hampton T. Fictions of Embassy. Cornell University Press Publ., 2009. 250 p.

10. Hennings J. Russia and Courtly Europe. Cam- bridge University Press Publ., 2016. 310 p. DOI: 10.1017/CBO9781107279599

11. Hughes L. Russia in the age of Peter the Great. Yale University Press Publ., 2000. 640 p.

12. Israel J. The Dutch Republic, Its Rise, Greatness, and Fall 1477-1806. Oxford, 1998. $1280 \mathrm{p}$.

13. Lowenson L. The First Interviews between Peter I and William III in 1697: Some Neglected Material. The Slavonic and East European Review, 1958, vol. 36, no. 87, pp. 308-316.

14. Nesca A. Robb William of Orange, A Personal Portrait. London, Heinemann Publ., 1966. Vol. II. 424 p.

15. Phyllis S. Lachs, The Diplomatic Corps under Charles II and James II. Rutgers University Press Publ., 1965. 269 p.

16. Price J.M. The Adventure to Russia, Enterprise, Politics and Diplomacy in the Quest for a Northern Market for English Colonial Tobacco, 1676-1722. Transactions of the American Philosophical Society. New Series. 1961. Vol. 51. No. 1. Pp. 1-120. DOI: 10.2307/1005870

17. Sadler C. Peter der Grosse als Mensch und Regent. St. Petersburge, $1872.298 \mathrm{p}$.

18. The Notebooks of Leonardo da Vinci. Comp. and ed. from the Original Manuscripts by J. P.Richter. In 2 vols. New York, 1972, vol. 1, 2. 866 p.

19. Britain and Russia, in the age of Peter the Great, Historical Documents. Ed. by S. Dixon. SEESS Occasional Papers, no. 38. London, School of Slavonic and East European Studies Publ., 1998. $255 \mathrm{p}$.

20. van der Zee H. and B. William and Mary. London, MacMillan Publ., 1973. 544 p.

\section{About the author:}

Maija Jansson - Ph.D in History, Director Emerita of the Yale Center for Parliamentary History. Department of History, Yale University. McClellan Hall, 1037 Chapel Street, P.O. Box 208324, New Haven, CT 06520-8324, USA. E-mail: maija.jansson@yale.edu.

\section{"NCOGNITO" И НОВАЯ ДИПЛОМАТИЯ: СЛУЧАЙ ПЕТРА І}

Майя Дженссон

DOI 10.24833/2071-8160-2018-6-63-13-34

Йельский университет 
Цель статьи - рассмотреть визиты Петра I incognito в Голландию и Англию в широком историческом контексте, показав, что это было не личным выбором царя, обусловленным исключительно его индивидуальными качествами, а способом поведения, заимствованным из сферы нового дипломатического протокола. Опыт пребывания Петра в Англии - один из наиболее ярких примеров нового понимания термина incognito в середине XVII в.

Сосредоточив внимание на этом случае, автор прослеживает эволюцию значений термина incognito, его употребления в литературном обиходе и шире - в дипломатической практике - по мере формирования этого понятия в ходе различных конгрессов и ассамблей того времени, начиная с подготовительных встреч, предшествовавших заключению Вестфальского мира.

Исследование основывается на анализе разнообразных записей и отчётов того времени - правительственных документов и архивов, а также мемуаров современников.

В заключение делается вывод о том, что практика путешествий послов или монархов incognito позволяла государственной казне экономить на пышных церемониях и многочисленных свитах. Для монархов ещё важнее было то, что они могли свободно перемещаться и избегать ограничений, которые накладывали на них формальные требования придворного церемониала.

Таким образом, действия Петра I, равно как и Вильгельма III, были важным моментом в процессе перехода от формализованных церемониальных отношений суверенов, характерных для периода «персональной монархии» в начале XVII столетия, к идее репрезентации суверенного государства посредством постоянного корпуса послов и полномочных представителей.

Ключевые слова: Incognito, Петр I, Вильгельм III, дипломатия, вестфальский мир, персональная монархия, полномочные представители

\section{Список литературы:}

1. Barany G. The Anglo-Russian Entente Cordiale of 1697-1698: Peter I and William III at Utrecht. New York, Eastern European Monographs, 1986. 101 p.

2. Berridge G.R., Keens-soper M., Otte T.G. Diplomatic Theory from Machiavelli to Kissinger, Studies in Diplomacy. Palgrave Macmillan Publ., 2001. 216 p. DOI: $10.1057 / 9780230508309$

3. Bushkovitch P. Patrick Gordon and Russian Court Politics // Journal of Irish and Scottish Studies. 2010. Vol. 3. Iss. 2. P. 11.

4. Bushkovitch P. Peter the Great, The Struggle for Power, 1671-1725. Cambridge, England, 2001. 187 p.

5. Chaplin J.E. Roanoke 'Counterfeited According to the Truth' // A New World, England's first view of America. Ed. by K.Sloan. Chapel Hill, 2007. Pp. 51-63.

6. Cross A. Peter the Great through British Eyes, Perceptions and Representations of the Tsar since 1698. London, Cambridge University Press, 2001. 208 p.

7. Dukes P., Graeme P. Herd, and Kotilaine J. Stuarts and Romanovs, the Rise of a Special Relationship. Dundee, Discovery Press, 2009. 256 p.

8. Gouzevitch D. et I. La Représentation of the Grande Ambassason de Pierre Ier (1697-1698) dans les journaux: la presse comme source pour les recherches historique // E-Journal of EighteenthCentury Russian Studies, IV. 2016, pp. 24-31.

9. Hampton T. Fictions of Embassy, Cornell University Press, 2009. 250 p.

10. Hennings J. Russia and Courtly Europe. Cambridge University Press, 2016. 310 p. DOI: $10.1017 / C B O 9781107279599$

11. Hughes L. Russia in the age of Peter the Great. Yale University Press, 2000. 640 p.

12. Israel J. The Dutch Republic, Its Rise, Greatness, and Fall 1477-1806. Oxford, 1998, 1280 p. 
13. Lowenson L. The First Interviews between Peter I and William III in 1697: Some Neglected Material // The Slavonic and East European Review. 1958. Vol. 36. No. 87. Pp. 308-316.

14. Nesca A. Robb William of Orange, A Personal Portrait. London, Heinemann, 1966, vol. II, 424 p.

15. Phyllis S. Lachs, The Diplomatic Corps under Charles II and James II. Rutgers University Press, 1965. 269 p.

16. Price J.M. The Adventure to Russia, Enterprise, Politics and Diplomacy in the Quest for a Northern Market for English Colonial Tobacco, 16761722 // Transactions of the American
Philosophical Society. New Series. 1961. Vol. 51. No. 1. Pp. 1-120. DOI: $10.2307 / 1005870$

17. Sadler C. Peter der Grosse als Mensch und Regent. St. Petersburge, 1872. 298 p.

18. The Notebooks of Leonardo da Vinci. Comp. and ed. from the Original Manuscripts by J. P.Richter. In 2 vols. New York, 1972, vol. 1, 2. 866 p.

19. Britain and Russia, in the age of Peter the Great, Historical Documents. Ed. by S. Dixon. SEESS Occasional Papers, no. 38. London, School of Slavonic and East European Studies, 1998. 255 p.

20. van der Zee H. and B. William and Mary. London, MacMillan, 1973. 544 p.

\section{O6 aвmope:}

Майя Дженссон - доктор истории, Почетный директор Йельского центра парламентской истории. Исторический факультет Йельского университета. Department of History, Yale University. McClellan Hall, 1037 Chapel Street, P.O. Box 208324, New Haven, СТ 065208324, USA. E-mail: maija.jansson@yale.edu. 